\title{
1306 ステレオ法を用いた自律移動ロボットの経路探索
}

Route Planning for Autonomous Mobile Robots Using Stereo Method

○学 松田 日嘉（德島大院）正 浮田 浩行（徳島大）

Hiyoshi MATSUDA, and Hiroyuki UKIDA

The University of Tokushima, 2-1 Minamijyousanjima-cho, Tokushima-shi, Tokushima

Key Words: Mobile Robot, Stereo Method, Epipolar Geometry

\section{1. 粕言}

近年, 多種多様な自律学習ロボットが開発されて おり，様々な移動手法が考案されている．それらの多 くがセンサーを多用する傾向にあるため，本実験では 装置の単純化と小型化を考え，小型カメラ一台を用い 任意のある位置, 姿勢から目標となる位置へ向かって ロボットを誘導することを目的とする．また，カメラ で取得する画像からの自己位置推定やステレオ法によ る物体の検出についても検討する.

\section{2. ロボットの経路探索}

2.1 実験概要 まず本研究で提案するロボットの経路 探索方法を示す。

（1）あらかじめ与えたロボット周囲の地図画像上で 現在位置を推定する。

（2）現在位置周辺において，ステレオ法を用い障害 物を検出する。

（3）検出した障害物を地図画像上に投影し，地図画 像を更新する.

（4）目標位置までの経路を地図画像上で探索する.

（5）更新された地図画像を参照して経路探索を行い, 目標位置までの最適な移動方向を選択する.

（6）経路探索によって選択した方向へロボットを移 動させる。

以上を繰り返すことにより，ロボットをある出発位置 からある目標位置まで自律的に誘導する。

これまではアームロボットに 3 眼カメラを搭載して, 上記（1）から（5）に相当するステレオ法による障 害物の検出と構築された地図画像からの経路探索を行 ってきた ${ }^{[1]}$.アームロボットを利用することにより正 確な移動が可能となりシミュレーションを行うには適 していたが，口ボット自体が大型な上，移動範囲が制 限されるという問題がある.

そこで本研究では Fig.1 に示すように, 1 眼カメラ を小型移動ロボットに搭載し，自己位置を推定しなが ら自律的に目標位置一誘導する方法について検討する. これは上記後半 (6) に相当する. 現段階では 1 眼力 メラによって目標位置まで誘導することを行っている が，最終的には 3 眼カメラを搭載し障害物を検出しな がらロボットの移動することを検討している。

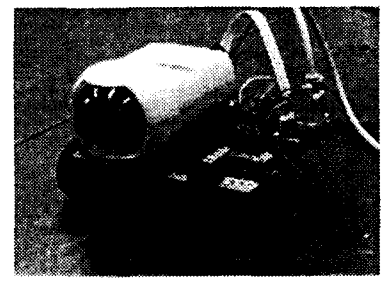

Fig. 1 Mobile Robot
2.2 画像間のエピポーラ幾何算出 ロボットの移動 にはエピポーラ幾何を用いる.エピポーラ幾何とは複 数の視点における相対的なカメラの位置や姿勢の情報 を記述する幾何のことである. 同一カメラの場合，移 動前後の視点においてェピポーラ幾何を算出すること でそのロボットの姿勢を知ることができる.

2.3 画像間の対応点抽出 エピポーラ幾何を算出す るにはまず二つの視点で取得した画像（第 1 ，第 2 画 像）の対応点を求める必要がある.

対応点として利用する特徽点の抽出にはハリスのコ ーナー検出手法を用いる.また，あらかじめガウシア ンフィルタを用いて画像を平滑化しておけば誤検出を 避けることができる.

対応点はこの手法によって求めた 2 枚の画像の特徴 点周辺においてテンプレートマッチングすることで得 ることができる。

2.4 対応点による位置誤差の算出 現在位置の画像 と目標位置の画像の対応点を比較（誤差算出）して目 標位置到達の判断や自己位置の推定を行う．2枚の画 像の対応点から得られる誤差算出には次に示す変換行 列 $\mathrm{P}$ を用いる. このP との変換によって求めた対応点 座標と実際の座標との差を位置誝差として, 目標位置 到達や自己位置推定に用いる.

$$
\begin{aligned}
& \widetilde{m}_{i}^{\prime}=P \tilde{m}_{i} \\
& \widetilde{m}_{i}=\left(\begin{array}{lll}
u & v & 1
\end{array}\right), \quad \tilde{m}_{i}^{\prime}=\left(\begin{array}{lll}
u^{\prime} & v^{\prime} & 1
\end{array}\right)
\end{aligned}
$$

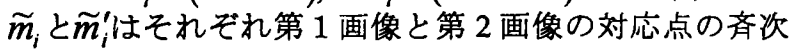
座標を表す。

また，この誤差の大きさを利用してテンプレートマ ッチングのテンプレートサイズの変更を行い，位置が 離れた 2 枚の画像間の対応点探索においても精度よく 求めることができる.

2.5 画像間の $\mathrm{F}$ 行列算出 $\mathrm{F}$ 行列 (Fundamental 行列) とは式(3)のようなエピポーラ方程式に含まれるエピ ポーラ幾何を計算するための基礎となる行列である.

$$
\tilde{m}^{\prime T} F \tilde{m}=0
$$

ここで $\mathrm{F}$ は $3 \times 3$ 行列である. 8 点以上の対応点座標 による条件を加えた行列を $M$ とし $M f=0$ とすると, $f$ は\|f\|=1 という条件のもとで $M^{T} M$ の最小固有值に対 応する固有べクトルとして求めることができる.

2.6 エピポーラ線とエピポールの算出 Fig.2のよう に視点 $\mathrm{c}, \mathrm{c}^{\prime}$ と 3 次元空閒中の任意の点 $\mathrm{x}$ はその空間

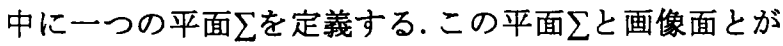
交差してできる直線 1, 1'をエピポーラ線と再ぶ。また, エピポールは二つの視点を結ぶ直線が画像面と結ぶ交

日本機械学会講演論文集 No.075-1（'07-3，中国四国支部 第45期総会・講演会） 
点 $\mathrm{e}, \mathrm{e}$ のことである.ひとたび $\mathrm{F}$ 行列が求まればエ ピポーラ線とエピポールを求めることができる.エピ ポーラ線を求めるためには次式を計算する.

$$
\tilde{l}^{\prime}=F \tilde{m}
$$

この $l^{\prime}$ を用いると (3) 式は $\tilde{m}^{\prime \prime} \widetilde{l}^{\prime}=0$ となり, $\boldsymbol{m}^{\prime}$ が末知 の変数とすると，これは第 2 画像上のひとつの直線を 表す.これがエピポーラ線である. 同様にして，第 1 画 像上のエピポーラ線も求めることが出来る.エピポー ルはエピポーラ線の交点である.

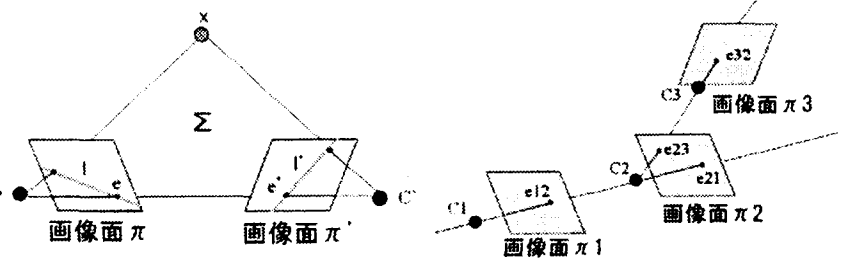

Fig.2 Epipolar line and epipole Fig.3 Relation of images

2.7 同一カメラのエピポーラ幾何と移勤原理 一つ のカメラを用いた画像面の関係を Fig.3に示す. ロボ ットを移動させるにはこの 3 枚の画像（移動前画像 $\pi$ 1 , 移動後の現在位置画像 $\pi 2$, 目標位置画像 $\pi 3$ とす

る）のエピポーラ幾何を利用する.

具体的には, 移動前画像 $\pi 1$ と移動後画像 $\pi 2$ より 求めたエピポール $\mathrm{e} 21$ と移動後画像と目標画像 $\pi 3$ よ り求めたエピポール e23に着目する. 同一カメラのエ ピポールはそのロボットの進行方向を示す.そこで, この二つの点において e21 方向から e23 方向へロボッ 卜を回転させることで目標画像取得方向へロボットの 姿勢を近付けることができる．続けて直進し，これを 絽り返すことでロボットは目標画像取得位置へ近づく. 2.8 ロボットの移動方法 次にロボットが移動する 際の詳細な流れを示す. 以下の流れを，2.1で述べた

（6）において行う.なおここで（3）の目標画像は. あらかじめ与えられているとする。

(1) 現在位置で画像を撮影する.

（2）ロボットを指定の方向へ移動し画像を撮影する.

(3) 現在位置画像と目標画像の対応点, 現在位置画 像と移動前画像の対応点を得る。

(4) 現在位置画像と目標画像の対応点から位置誤差 を算出する．誤差が闘值以下であればこの時点で移動 完了とする.

（5）現在位置画像と目標画像, 現在位圆画像と移動 前画像のエピポーラ幾何をそれぞれ算出する。

（6）算出したエピポーラ幾何により目標画像方向へ の姿勢を得る.（2）へ戻り，これを繰り返すことに よりロボットは目標画像取得位置へ誘導される.

エピポーラ幾何を算出するには画像間の対応点が求 まらなければならないため，目標位置や障害物の位置 の関係によっては一枚の目標画像では到達できない. そのため，一時的な目標位置までの画像を参照し，そ れを切り替えながら最終的な目標位置へ到達させるこ とを検討している.

\section{3. 実験}

Fig. 1 に示すカメラを搭載した移動ロボットを用い て実験を行った。Fig.4 はあらかじめ与えた目標位置 の画像である. そして，Fig.6 中において四角で示す 6 つの出発点から一つの目標位置へ向けて, エピポー
ラ幾何を計算しながら自律的に移動させる.Fig.5 は Fig.6 中の黒四角で示す出発位置の画像である. 実験 結果を Fig.6に示す. 図中の直線がロボットの移動軌 跡である。また，直進移動に関しては別に自己位置推 定を行った. その結果を Fig.7 に示す. 直線が実際の 移動，折れ線が推定位置の軌跡となっている.

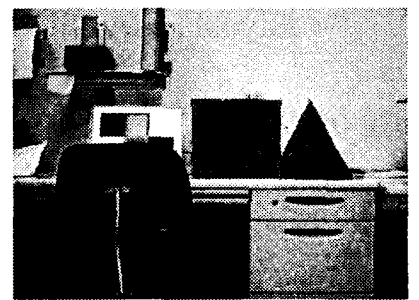

Fig. 4 The goal image

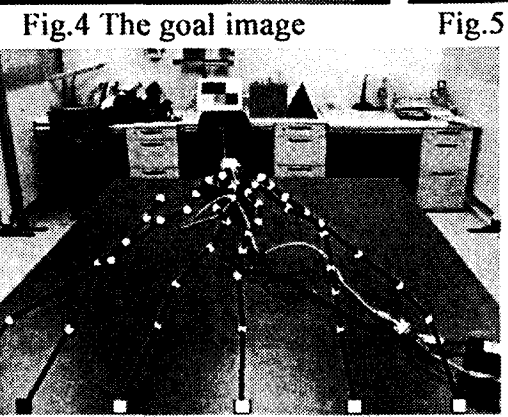

Fig.5 The start image

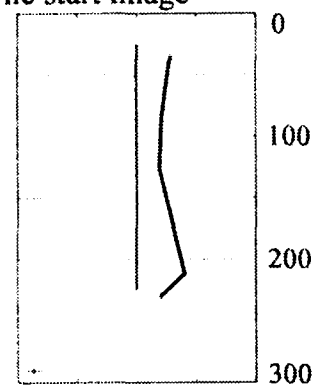

300

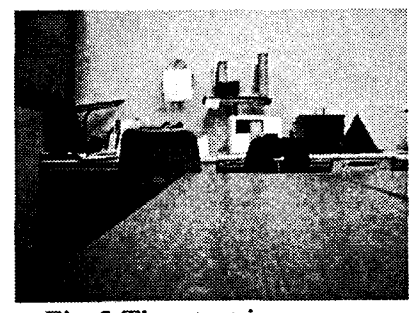

Fig.6 Trajectory of robot move Fig.7 Location Estimation

\section{4. 考察}

エピポーラ幾何を正確に算出するには，2 枚の画像 間での対応点を確実に取ることが不可欠であるが，本 実験では 2.4 に示したように目標位置と現在位置の位 置誤差をテンプレートサイズ変更の制御に利用するこ とで誤検出を防いでいる，しかし，対応点座標の多少 の誤差から安定してエピポーラ幾何を算出できない場 合もある.

ロボットの移動においては, 目標位置へ向かって制 御されているが，一回の回転・移動量をより小さくす れば不安定な計算結果の影響を大きく受けることなく, 移動自体もより正確なものになると考えられる.

位置誤差を利用した自己位置推定では，その移動方 向などは推定できているが，実際の自己位置とは違っ た位置として判断してしまっている.これはあらかじ め与えておく周辺画像の取得枚数の少なさや対応点座 標の誤差などによる.

\section{5. 结言}

本実験では小型カメラを搭載した移動ロボットにお ける，目標位置への経路誘導について述べた．今後は， あらかじめ目標画像を取得する方法を検討する.

\section{考支获}

[1]松田日嘉, 浮田浩行 : 自律移動ロボットの経路探 索, FIT2006一般講演論文集, pp.157-158

[2] 佐藤岳晴, 佐藤淳 : 未公正カメラによる未公正口 ボットの視覚サーボ，電子情報通信学会論文誌 2000 年 4 月 pp.1110-1118

[3] 佐藤淳 : コンピュータビジョンー視覚の幾何ーコ ロナ社

[4] 奥富正敏, ディジタル画像処理, CG-ARTS 協会 